\title{
Rapid Method for Isolation of PCR Amplifiable Genomic DNA of Ralstonia solanacearum Infested in Potato Tubers
}

\author{
Alka Grover ${ }^{1 *}$, Swarup K. Chakrabarti ${ }^{2}$, Wamik Azmi ${ }^{3}$, S. M. P. Khurana ${ }^{4}$ \\ ${ }^{1}$ Amity Institute of Biotechnology, Amity University, Noida, India \\ ${ }^{2}$ Division of Crop Protection, Central Potato Research Institute, Shimla, India \\ ${ }^{3}$ Department of Biotechnology, Himachal Pradesh University, Shimla, India \\ ${ }^{4}$ Amity Institute of Biotechnology, Amity University, Gurgaon, India \\ Email: ${ }^{*}$ alkagrover@hotmail.com
}

Received July 2, 2012; revised October 9, 2012; accepted November 19, 2012

\begin{abstract}
The aim of the present study was to develop a very fast and simple genomic DNA isolation method for Ralstonia solanacearum which infest potato tubers. One hundred potato tubers were collected and ten composite samples were prepared having 10 tubers each. Four different DNA isolation methods were used for bacterial genomic DNA isolation present in tubers. PCR with $R$. solanacearum specific primers and pathogenicity tests were performed. Out of four methods two gave PCR amplifiable DNA. The simplest method was boiling the cell lysate for 5 min, vortexing for 2 min then extraction with phenol chloroform method. This method provides significant amount of DNA which is free from contaminants thus rendering the DNA amicable to PCR amplification. The developed method would be useful for quick and sensitive detection of this pathogen in seed potatoes and would be beneficial to stop the further spread of pathogen.
\end{abstract}

Keywords: Ralstonia solanacearum; PCR; Detection; Potato; DNA

\section{Introduction}

The potato is the most popular non-cereal food crop of the world and ranks fourth in importance after rice, wheat and maize. Potato is the most widely consumed vegetable in India. India is the second largest producer of potato contributing to $10 \%-11 \%$ of the world potato production after China, and contributes a share of $22 \%$ of the world production [1]. Growth rate of potato is facing some constraints. One of these constraints is bacterial wilt disease. Bacterial wilt/brown rot are the most destructive bacterial disease of potato caused by Ralstonia solanacearum [2]. In India alone more than 130 plant species belonging to 47 genera have been reported to be infected by this pathogen [3]. Losses as high as $75 \%$ have been reported to potato crops from India and have caused potato to be temporarily abandoned in some areas, such as Bihar [4].

The ability of the bacterium to infect a large number of hosts makes its control rather difficult. To date, no effective control methods exist for bacterial wilt disease.

Resistant varieties, field sanitation, crop rotation and use of bactericides have met, if at all, with only limited successes [5]. Furthermore, the high variability of strains

"Corresponding author. of $R$. solanacearum [5,6] coupled with the influence of environmental factors on host pathogen interactions often restrict the expression of resistance in specific regions.

Use of healthy seeds is the most effective way to avoid introduction and dissemination of this pathogen in disease free areas. In order to have healthy seeds very sensitive and accurate detection methods are required. For quicker detection of the pathogen, immunodiagnostics [7] and polymerase chain reaction based tests $[8,9]$ have been developed (based on PCR amplification of DNA and RNA). The PCR based techniques are more sensitive and specific as compared to immunodiagnostic methods and can be used for detection of ultra-low population of $R$. solanacearum in potato tubers [9].

Despite the high sensitivity and speed of PCR method, detection of $R$. solanacearum in potato tubers using PCR assay is not certain [10]. This is due to the presence of polysaccharides and phenolic compounds in potato tuber extracts which act as inhibitors of Taq DNA polymerase $[10,11]$. Therefore to test the latent infection of bacteria in potato tubers through PCR, it is mandatory to isolate good quality bacterial DNA from tubers. For quarantine purpose the method should be simple, quick, should warrant the removal of inhibitory substances and give the high yield of amplifiable DNA. 
In the present study we are reporting a very fast and effective bacterial genomic DNA isolation method for PCR detection of $R$. solanacearum in potato tubers.

\section{Materials and Methods}

\subsection{Collection of Potato Tubers}

For standardization of DNA isolation method, one hundred tubers were collected from wilt infested fields of Central Potato Research Institute, Shimla, India during one cropping season. Tubers were randomly selected from heaps at harvest, at the beginning of the storage period, between 4 and 12 weeks after harvest.

\subsection{Sample Analysis}

The tubers were washed under running water and airdried. One hundred tubers were randomly divided into 10 composite samples of 10 tubers each. The skin was removed at the heel end of the tuber with a clean and disinfected vegetable knife so that the vascular tissues first became visible. A small conical core (3 - $5 \mathrm{~mm}$ diameter) of vascular tissue at the heel end was carefully cut out. The amount of nonvascular tissue was kept to a minimum. A composite sample of heel ends of 10 tubers was crushed together with the help of pestle and mortar and collected in a sterile Falcon tube containing $5 \mathrm{~mL}$ of double distilled water making a homogenate then samples were allowed to stand for $30 \mathrm{~min}$.

The supernatant was gently decanted in a centrifuge tube and centrifuged at $7000 \times \mathrm{g}$ for $15 \mathrm{~min}$ at $10^{\circ} \mathrm{C}$. The pellet was resuspended in $1-\mathrm{mL}$ sterile water and a cell homogenate was prepared.

\subsection{DNA Purification}

Following four different methods were used for bacterial chromosomal DNA isolation from cell homogenate.

a) The cell homogenate was boiled for $5 \mathrm{~min}$ and directly used for PCR amplification.

b) The cell homogenate was boiled for 5 min then vortexed for $2 \mathrm{~min}$ and DNA was extracted with phenol: chloroform:isoamylalcohol $(25: 24: 1)$ and precipitated by adding 0.1 volume of ammonium acetate and 2 volumes of chilled ethanol [12].

c) The cell homogenate was treated with Murmur's method [13] for genomic DNA isolation of bacteria.

In this method, to $1-\mathrm{mL}$ of cell homogenate $100 \mu \mathrm{L}$ of extraction medium ( $0.15 \mathrm{M} \mathrm{NaCl}$; $0.1 \mathrm{M} \mathrm{Na}_{2}$ EDTA) and $100 \mu \mathrm{L}$ of lysozyme $\left(10 \mathrm{mg} \cdot \mathrm{mL}^{-1}\right)$ was added, incubated at $37^{\circ} \mathrm{C}$ for 30 min shaking occasionally. After incubation the lysis was completed by adding $200 \mu \mathrm{L}$ of $25 \%$ SDS solution. The mixture was heated at $60^{\circ} \mathrm{C}$ in a water bath then cooled to room temperature. To this mixture sufficient amount of $5 \mathrm{M}$ sodium per chlorate was added to a final concentration of $1 \mathrm{M}$. An equal volume of chloroform:iso amyl alcohol (24:1) was added to the lysed preparation suspended in $1 \mathrm{M}$ sodium per chlorate and shaked slowly (30 - 60 oscillations $\cdot \mathrm{min}^{-1}$ ) for $30 \mathrm{~min}$ at room temperature. The resulting emulsion was separated by centrifuging for $5 \mathrm{~min}$ at 10,000 rpm at room temperature. After centrifugation top clear aqueous phase was pipetted out and placed in a fresh eppendorf tube. DNA was precipitated out by adding 2 volumes of $95 \%$ ethanol to the clear aqueous phase. This crude DNA preparation was dissolved in $900 \mu \mathrm{L}$ of dilute $\left(10^{-1}\right.$ fold) saline citrate $(0.15 \mathrm{M}$ sodium chloride, $0.015 \mathrm{M}$ tri sodium citrate) and an even solution was prepared. To this even solution $100 \mu \mathrm{L}$ of $3 \mathrm{M}$ sodium acetate and $1 \mathrm{mM}$ EDTA pH 7.0 solution was added and a uniform suspendsion was prepared. The prepared suspension was transferred to another tube containing $540 \mu \mathrm{L}$ of isopropanol and DNA was precipitated out. The DNA was washed first with $70 \%$ ethanol and then with $95 \%$ ethanol. Removed alcohol from the precipitated DNA by blotting with a clean piece of filter paper and then finally dissolved the DNA in $100 \mu \mathrm{L}$ of ultra pure sterile water.

d) The cell homogenate was treated with ProteinaseK-SDS lysis miniprep method for genomic DNA extraction [14].

For genomic DNA isolation $1.5 \mathrm{~mL}$ of cell homogenate was centrifuged for $2 \mathrm{~min}$ in a micro centrifuge. Resuspended the pellet in $567 \mu \mathrm{L}$ TE buffer by repeated pipetting then added $30 \mu \mathrm{L}$ of $10 \%$ SDS and $3 \mu \mathrm{L}$ of 20 $\mathrm{mg} \cdot \mathrm{mL}^{-1}$ proteinase $\mathrm{K}$ to give a final concentration of $100 \mu \mathrm{g} \cdot \mathrm{mL}^{-1}$ proteinase $\mathrm{K}$ in $0.5 \%$ SDS. Mixed thoroughly and incubated for $1 \mathrm{hr}$ at $37^{\circ} \mathrm{C}$. To this mixture added $100 \mu \mathrm{L}$ of $5 \mathrm{M} \mathrm{NaCl}$, mixed thoroughly then added $80 \mu \mathrm{L}$ of $\mathrm{CTAB} / \mathrm{NaCl}$ solution. Mixture was incubated for $10 \mathrm{~min}$ at $65^{\circ} \mathrm{C}$. An approximately equal volume $(0.7$ to $0.8 \mathrm{~mL})$ of Phenol:Chloroform:Isoamyl alcohol (25:24:1) was added and mixed thoroughly, and spun for 4 to $5 \mathrm{~min}$ in a micro centrifuge. The aqueous, viscous supematant was removed to a fresh microcentrifuge tube, leaving the interface behind. An equal volume of chloroform:isoamyl alcohol (24:1) was added to extract thoroughly, and spun in a microcentrifuge for $5 \mathrm{~min}$. The aqueous phase was transferred to a fresh tube. DNA was extracted with 0.6 vol. isopropanol. The precipitate was washed with $70 \%$ ethanol. The supernatant was removed and pellet was briefly dried. The pellet was resuspended in $100 \mu \mathrm{L}$ TE buffer. The precipitated DNA pellet was washed with $70 \%$ ethanol and resuspended in $100 \mu \mathrm{L}$ sterile ultra pure water.

Quantity and quality of DNA preparations were checked by standard spectrophotometry and gel electrophoresis and all the samples were diluted to $10 \mathrm{ng}$ DNA per microlitre.

Ralstonia solanacearum infested potato tubers were 
used as positive control and potato tubers that were clean to Ralstonia solanacearum were included as negative control.

\subsection{PCR Amplification}

Total 10 DNA isolate mixtures were used in amplification. PCR was performed in a reaction volume of $25 \mu \mathrm{L}$ containing 1X Taq polymerase buffer with $1.5 \mathrm{mmol} \cdot \mathrm{L}^{-1}$ of $\mathrm{MgCl}_{2}$ (PE Applied Biosystem, Foster City, CA, USA), $100 \mu \mathrm{L} \cdot \mathrm{mol} \cdot \mathrm{L}^{-1}$ of each dNTP (PE Applied Biosystem), 0.5 pmol of primer, $10 \mathrm{ng}$ of genomic DNA and 1.0 U of Taq DNA polymerase (AmpliTaq; PE Applied Biosystem).

PCR amplifications were performed in a thermal cycler (GENAMP PCR SYSTEM 9700; Applied Biosystems). Primers specific to $R$. solanacearum $16 \mathrm{~S}$ rDNA (Y2-OLI 1) [15] were used for PCR amplification. The thermal conditions for Y2-OLI1 primer pair were $\left[94^{\circ} \mathrm{C}\right.$, $5 \mathrm{~min}$ (one cycle); $94^{\circ} \mathrm{C}, 1 \mathrm{~min}, 35.5^{\circ} \mathrm{C}, 1 \mathrm{~min}, 72^{\circ} \mathrm{C}, 2$ min $\left(45\right.$ cycles); $72^{\circ} \mathrm{C}, 10 \mathrm{~min}$ (one cycle)]. The amplified products were resolved in $0.8 \%$ agarose gel, stained with ethidium bromide and photographed under UV light. Negative and positive controls were included in PCR reactions.

Reproducibility of PCR reactions was checked by performing duplicate reactions for each template DNA isolated. DNA templates used in the study were able to give reproducible PCR amplification results in duplicated experiment. Amplified products were separated by electrophoresis in $1.0 \%$ agarose gels with $0.5 \mu \mathrm{g} \cdot \mathrm{mL}^{-1}$ of ethidium bromide at $4 \mathrm{~V} \cdot \mathrm{cm}^{-1}$ constant voltages for $2 \mathrm{~h}$. The gels were scanned in FluorS MultiImager (Bio-Rad Laboratories, Hercules, CA, USA).

\subsection{Pathogenicity Testing}

All the Positive results of PCR were confirmed by pathogenicity test. To check the pathogenicity around $100 R$. solanacearum isolates were isolated from the same infected potato (Solanum tuberosum L.) tubers which were used for bacterial genomic DNA isolation, by standard procedure on casamino acid peptone glucose (CPG) agar medium [16]. For each isolate, a single well-separated fluidal colony from CPG agar plate was selected and grown in liquid CPG broth (TTC medium without agar and triphenyl tetrazolium chloride) for $48 \mathrm{~h}$ at $28^{\circ} \mathrm{C}$ prior to storage with $20 \%$ glycerol at $80^{\circ} \mathrm{C}$. Individual isolate was also maintained in sterile double distilled water at $20^{\circ} \mathrm{C}$ for maintenance of virulence [17]. To revive an isolate, the stored culture was streaked on TTC agar medium and well-separated fluidal colonies were selected. Identity of all the isolates was checked by diagnostic tests like $\mathrm{KOH}$ (4\% solution in water), oxidase and urease tests [3].
Biovar of each isolate was determined by standard procedure [18]. The following basal medium was used for biovar identification: $\mathrm{NH}_{4} \mathrm{H}_{2} \mathrm{PO}_{4}, 1.0 \mathrm{~g}$; KCl, $0.2 \mathrm{~g}$; $\mathrm{MgSO}_{4} \cdot 7 \mathrm{H}_{2} \mathrm{O}, 0.2 \mathrm{~g}$; Peptone, $1.0 \mathrm{~g} ; 1 \%(\mathrm{wv})^{-1}$, aqueous solution of bromothymol blue, $0.3 \mathrm{~mL}$; agar, $1.5 \mathrm{~g}$; distilled water, 11. The $\mathrm{pH}$ of the medium was adjusted to 7.1 with $40 \%(\mathrm{wv})^{-1} \mathrm{NaOH}$ solution before addition of the agar. Five millilitres of a $10 \%(\mathrm{wv})^{-1}$ presterilized solution of the carbohydrates were added to $45 \mathrm{~mL}$ of molten cooled basal medium, which was then dispensed in sterile plugged tubes $(1 \times 12.5 \mathrm{~cm})$ to a depth of about $4 \mathrm{~cm}$. With a sterile Pasteur pipette, $0.1 \mathrm{~mL}$ of 2-day-old $R$. solanacearum cultures (OD: 0.1 at $600 \mathrm{~nm}$ ) was added to each tube containing basal medium and carbohydrate solution. The inoculated tubes were incubated at $30^{\circ} \mathrm{C}$ and examined at 3, 7 and 14 days for change of $\mathrm{pH}$ (yellow color) from the top downwards. Two replicates for each test were used along with appropriate control with no carbohydrate.

Race identification of the isolates was done based on the procedure described by He et al. [19]. Five plants of potato, tomato, eggplant, pepper, tobacco and peanut were grown in pots containing steam-sterilized soil:peat: sand (1:1:1 by volume) mixture. The plants were inoculated by stem stab method [20] when they were about 15 - $20 \mathrm{~cm}$ tall. The inoculated plants were incubated at $28^{\circ} \mathrm{C}$ $\pm 8^{\circ} \mathrm{C}$ and were observed for wilt appearance after 21 days.

Pathogenicity test was performed by inoculating the tomato plants as described by Winstead and Kelman [20]. The pathogen was inoculated by stem stab method [20] in four weeks' old tomato seedlings of variety Pusa Ruby that is known to be susceptible to $R$. solanacearum. The inoculum consisted of a suspension of $1 \times 10^{8} \mathrm{cfu} \cdot \mathrm{mL}^{-1}$ in sterile distilled water. The inoculated plants were incubated in a glass house for $16 \mathrm{~h}$ at $28^{\circ} \mathrm{C}$ during daytime and for $8 \mathrm{~h}$ at $24^{\circ} \mathrm{C}$ at night at a relative humidity of $70 \%$ - $80 \%$. Plants were observed weekly for symptoms over a period of five weeks. Healthy tomato seedlings, inoculated by the same procedure with sterile distilled water were used as negative control and tomato seedlings inoculated with a known $R$. solanacearum strain (CSG 40) as positive control.

\section{Result}

\subsection{Isolate Analysis}

Appearance of purple color within $10-60 \mathrm{~s}$ in oxidase test; violet color in urease test; formation of a fine threadlike slime in $\mathrm{KOH}$ test indicated that all the isolates belonged to $R$. solanacearum. All 100 isolates belonged to race 1 and biovar III.

\subsection{Pathogenicity Testing}

The wilting was recorded in seedlings up to 2 - 3 weeks 
after inoculation.

\subsection{PCR Amplification}

The specific primers Y2 and OLI 1 amplified a specific DNA fragment of size approximately $288 \mathrm{bp}$ with bacterial genomic DNA which was extracted through method $\mathrm{b}$ and method d. DNA isolated through protocol a and c was not PCR amplifiable. Figure 1 shows the results of PCR amplification. The simplest method was vortexing after boiling and then purification with phenol/chloroform (method $b$ ). This method takes hardly 30 minutes for bacterial genomic DNA isolation from potato tubers and no costly enzymes were involved.

\section{Discussion}

Ralstonia solanacearum causes extensive losses to crops in subtropical and tropical areas thus the rapid identification of the pathogen is most important for disease management. To our information, there was no fast bacterial genomic DNA isolation method from potato tubers that can be used in PCR assay detecting directly the pathogen $R$. solanacearum from potato tubers without culture; although many related methods were reported $[10,21]$. In the present study four different protocols were screened, and found that PCR amplifiable DNA samples were obtained with the method (b) and (d) but the fastest method was boiling the cell homogenate, vortexing and then purification with phenol chloroform (b). This method takes only $30 \mathrm{~min}$ to isolate PCR amplifiable bacterial genomic DNA from potato tubers. One DNA sample was also amplified in method a, lane 16; however the amplifica- tion results were not reproducible and the reliability of each DNA extraction method was defined in terms of consistency of the results in the three replicates.

Theoretically, the PCR technique is able to detect as few as single copy of target DNA. In practice, however, sensitivity of PCR reaction depends upon recovery of target DNA sequence and efficiency of the PCR reaction. Taq DNA polymerase enzyme is sensitive to inhibition by compounds present in biological samples [10] and a number of chemicals used in DNA extraction procedures [22]. Choice of DNA isolation method depends upon the type of sample in respect to purity and yield of the DNA obtainable. Several methods have been described [23-25] and numerous commercial kits are available for DNA isolation from plant tissues, based on different methodologies. Most of these methods have been optimized for DNA isolation from plant tissues but in this study we have developed a novel method which is able to isolate genomic DNA of bacteria, infesting potato tubers. To obtain enough amplifiable DNA from the potato homogenates, vortexing of boiled homogenate was important step before purification of the cell lysate with phenol-chloroform (method (b)). Mechanical homogenizers, manual homogenizers, mortar and pestles, sonicators, mixer mills, and vortexers are several of the more common tools used for mechanical and physical disruption [26] of the cells. In previous studies [10,21]. DNA isolation protocols were developed for artificially infested tubers but ours protocol was developed for naturally infested potato tubers and was also cross checked with artificially infested samples. Seal et al. (1993) [15] developed a PCR assay to detect $R$. solanacearum in potato
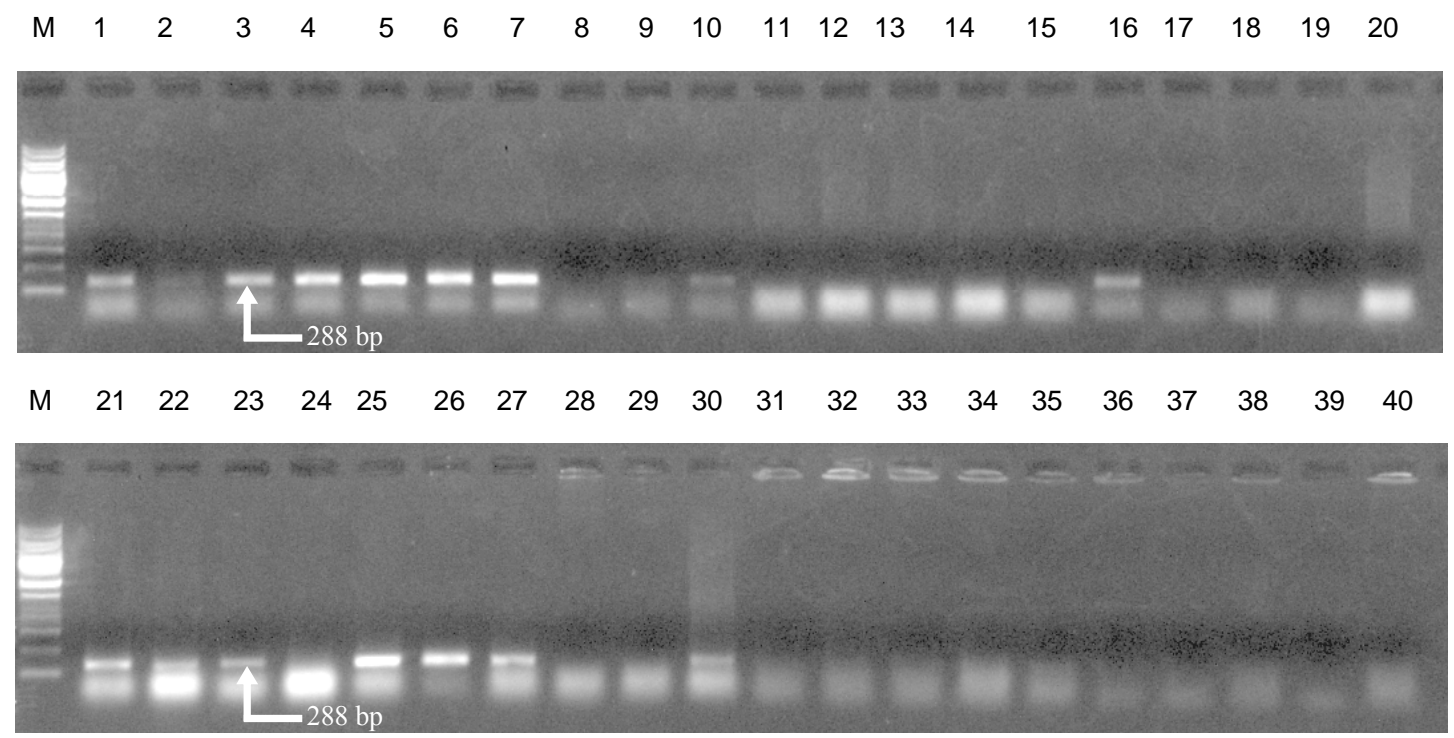

Figure 1. PCR amplification of bacterial genomic DNA isolated from potato tubers with primer pair Y2/OLI1. Lane 1 to 10: Bacterial genomic DNA extracted with method (b). Lane 11 to 20: Bacterial genomic DNA extracted with method (a). Lane 21 to 30: Bacterial genomic DNA extracted with method (d). Lane 31 to 40: Bacterial genomic DNA extracted with method (c). M represents 1 kb DNA ladder (MBI Fermentas; FERMENTAS Inc., Hanover, MD, USA). 
tuber homogenate by crude cell lysis without purification step but the results were inconsistent. Pastrik and Maiss (2000) [10] compared 10 different DNA extraction methods for the extraction of $R$. solanacearum DNA from potato homogenates and the most reliable results were obtained using the optimized Easy-DNA extraction kit. Niepold (1999) [21] standardized a DNA isolation method from potato tubers based on the $\mathrm{NaOH}$ alkaline boiling procedure using a mixture of lysozyme and proteases combined with minimized TRIS/HCl/BSA buffer to obtain amplifiable DNA from two quarantine bacteria $R$. solanacearum and Clavibacter michiganensis sp sepedonicus.

Co-solvents have been reported to be useful for some PCR reactions [27] but in our study there was no need of adding an additive as well as the enzymes as the DNA isolation method was reproducible enough. Enrichment [28] can increase the reliability and sensitivity of PCR reaction but we did not examine this step because it increases the complexity of protocol. This method will significantly contribute towards disease management by reducing the onset of disease through infested seed tubers.

\section{Acknowledgements}

The authors are grateful to Director AIB, Amity University, Noida UP for providing necessary facilities to undertake this study.

\section{REFERENCES}

[1] http://www.commodityindia.com/templates/more_articles .aspx? gid=All\&fn=Potato031111

[2] A. C. Hayward, "Biology and Epidemiology of Bacterial Wilt Caused by Pseudomonas solanacearum," Annual Review of Phytopathology, Vol. 29, 1991, pp. 65-87. doi:10.1146/annurev.py.29.090191.000433

[3] G. S. Shekhawat, A. V. Gadewar and S. K. Chakrabarti, "Potato Bacterial Wilt in India," Technical Bulletin, Shimla, Vol. 38, 2000, p. 56.

[4] A. V. Gadewar, V. Sunaina and S. K. Chakrabarti, "Bacterial Diseases of Potato and Their Management," In: S. M. P. Khurana, J. S. Minhas and S. K. Pandey, Eds., The Potato: Production and Utilization in Sub-Tropics, Mehta Publishers, New Delhi, 2003.

[5] M. I. Siri, A. Sanabria and M. J. Pianzzola, "Genetic Diversity and Aggressiveness of Ralstonia solanacearum Strains Causing Bacterial Wilt of Potato in Uruguay," Plant Disease, Vol. 95, No. 10, 2011, pp. 1292-1301. doi:10.1094/PDIS-09-10-0626

[6] A. Grover, W. Azmi, A. V. Gadewar, D. Pattanayak, P. S. Naik, G. S. Shekhawat and S. K. Chakrabarti, "Genotypic Diversity in a Localized Population of Ralstonia Solanacearum as Revealed by Random Amplified Polymorphic DNA Markers," Journal of Applied Microbiology, Vol. 101, No. 4, 2006, pp. 798-806. doi:10.1111/j.1365-2672.2006.02974.x

[7] K. Anitha, S. K. Chakrabarty, G. A. Girish, R. D. V. J. P. Rao and K. S. Varaprasad, "Detection of Bacterial Wilt Infection in Imported Groundnut Germplasm," Indian Journal of Plant Protection, Vol. 32, 2004, pp. 147-148.

[8] J. Schonfeld, H. Heuer, J. V. Elsas, K. Smalla and J. D. van Elsas, "Specific and Sensitive Detection of Ralstonia solanacearum in Soil on the Basis of PCR Amplification of Flic Fragments," Applied and Environmental Microbiology, Vol. 69, No. 12, 2003, pp. 7248-7256. doi:10.1128/AEM.69.12.7248-7256.2003

[9] A. Grover, W. Azmi, S. M. P. Khurana and S. K. Chakrabarti, "Multiple Displacement Amplification as a PrePolymerase Chain Reaction (Pre-PCR) to Detect Ultra Low Population of Ralstonia solanacearum (Smith 1896) Yabuchi et al. (1996)," Letters in Applied Microbiology, Vol. 49, No. 5, 2009, pp. 539-543. doi:10.1111/j.1472-765X.2009.02687.x

[10] K. H. Pastrik and E. Maiss, "Detection of Ralstonia solanacearum in Potato Tubers by Polymerase Chain Reaction," Journal of Phytopathology, Vol. 148, No. 11-12, 2000, pp. 619-626. doi:10.1046/j.1439-0434.2000.00567.x

[11] S. Poussier, J. J. Cheron, A. Couteau and J. Luisetti, "Bacterial Wilt Disease and the Ralstonia solanacearum Species Complex," APS Press, Saint Paul, 2005.

[12] J. Sambrook, E. F. Fritsch and T. A. Maniats, "Molecular Cloning: A Laboratory Manual," Cold Spring Harbor Laboratory Press, New York, 1989.

[13] J. Murmur, "A Procedure for the Isolation of Deoxyribonucleic Acid from Micro-Organisms," Journal of Molecular Biology, Vol. 3, 1961, pp. 208-218. doi:10.1016/S0022-2836(61)80047-8

[14] F. H. Ausbel, R. Brent, R. E. Kingston, D. D. Moore, J. G. Seidman, J. A. Smith and K. Struth, "Current Protocols in Molecular Biology," John Wiley and Sons, Hoboken, 1994.

[15] S. E. Seal, L. A. Jackson, J. P. W. Young and M. J. Daniels, "Differentiation of Pseudomonas solanacearum, Pseudomonas syzygii, Pseudomonas pickettii and Blood Disease Bacterium by Partial 16S rRNA Sequencing: Construction of Oligonucleotide Primers for Sensitive Detection by Polymerase Chain Reaction," Journal of General Microbiology, Vol. 139, No. 7, 1993, pp. 15871594. doi:10.1099/00221287-139-7-1587

[16] A. Kelman, "The Relationship of Pathogenicity of Pseudomonas solanacearum to Colony Appearance in a Tetrazolium Medium," Phytopathology, Vol. 44, 1954, pp. 693-695.

[17] L. Overbeek, J. H. W. Bergervoet, F. H. H. Jacobs and J. Elsas, "The Low-Temperature-Induced Viable-but-Nonculturable State Affects the Virulence of Ralstonia solanacearum Biovar 2," Phytopathology, Vol. 94, No. 5, 2004, pp. 463-469. doi:10.1094/PHYTO.2004.94.5.463

[18] A. C. Hayward, "Characteristics of Pseudomonas solanacearum," Journal of Applied Bacteriology, Vol. 27, No. 2, 1964, pp. 265-277. doi:10.1111/j.1365-2672.1964.tb04912.x

[19] L. He, L. Sequeira and A. Kelman, "Characteristics of 
Strains of Pseudomonas solanacearum from China," Plant Disease, Vol. 67, 1983, pp. 1357-1361. doi:10.1094/PD-67-1357

[20] N. N. Winstead and A. Kelman, "Inoculation Techniques for Evaluating Resistance to Pseudomonas solanacearum," Phytopathology, Vol. 42, 1952, pp. 628-634.

[21] F. Niepold, "A Simple and Fast Extraction Procedure to Obtain Amplifyable DNA from Ralstonia (Pseudomonas) solanacearum and Clavibacter michiganensis ssp Sepedonicus Inoculated Potato Tuber Extracts and Naturally Infected Tubers to Conduct a Polymerase Chain Reaction (PCR)," Journal of Phytopathology, Vol. 147, 1999, pp. 249-256. doi:10.1046/j.1439-0434.1999.147004249.x

[22] D. N. Miller, J. E. Bryant, E. L. Madsen and W. C. Ghiorse, "Evaluation and Optimization of DNA Extraction and Purification Procedures for Soil and Sediment Samples," Applied and Environmental Microbiology, Vol. 65, No. 11, 1999, pp. 4715-4724.

[23] H. J. Rogers, N. A. Burns and H. C. Parkes, "Comparison of Small Scale Methods for the Rapid Extraction of Plant DNA Suitable for the PCR Analysis," Plant Molecular Biology Reporter, Vol. 14, No. 2, 1996, pp. 170-183. doi:10.1007/BF02684906
[24] G. C. Allen, M. A. Flores-Vergara, S. Krasynanski, S. Kumar and W. F. Thompson, "A Modified Protocol for Rapid DNA Isolation from Plant Tissues Using Cetyltrimethylammonium Bromide," Nature Protocols, Vol. 1, No. 5, 2006, pp. 2320-2325. doi:10.1038/nprot.2006.384

[25] K. A. Lutz, W. Wang, A. Zdepski and T. P. Michael, "Isolation and Analysis of High Quality Nuclear DNA with Reduced Organellar DNA for Plant Genome Sequencing and Resequencing," BMC Biotechnology, Vol. 11, No. 54, 2011, pp. 1-9. doi:10.1186/1472-6750-11-54

[26] D. W. Burden, "Guide to the Homogenization of Biological Samples," Random Primers, Vol. 7, 2008, pp. 1-14.

[27] S. Bereswill, P. Bugert, I. Bruchmueller and K. Geider, "Identification of the fire Flight Pathogen Erwinia Amylovora by PCR Assay with Chromosomal DNA," Applied and Environmental Microbiology, Vol. 61, 1995, pp. 26362642.

[28] S. Priou, L. Gutarra and P. Aley, "An Improved Enrichment Broth for the Sensitive Detection of Ralstonia solanacearum (Biovars 1 and 2A) in Soil Using DASELISA," Plant Pathology, Vol. 55, 2006, pp. 36-45. doi:10.1111/j.1365-3059.2005.01293.x 